\title{
Travessia do herói e pertencimento à ordem do coletivo ${ }^{1}$
}

\section{The Hero's traverse and belonging to the collective order}

Henri Arraes Gervaiseau² 


\section{Resumo}

O filme Lost, lost, lost (1976), de Jonas Mekas, recompõe o percurso de uma travessia iniciada com um involuntário processo de distanciamento de um território de origem. Discuto as heterogêneas estratégias de registro escolhidas e os modos privilegiados de composição dos materiais, no processo de construção do relato, para dar conta de vivências afetivas e sócio-históricas evocadas pelo narrador-diretor. Em função do entrelaçamento enigmático das matérias de expressão, pontuamos que é árdua a análise da narrativa, mas que podemos, entretanto, apreender o sentido do desenho proposto da travessia. E mostramos que a apontada recomposição final pelo narrador do seu próprio eu está relacionada à emergência de sentimentos de pertencimento que remetem à dimensão do coletivo.

\section{Palavras-chave}

Território, travessia, pertencimento, Mekas.

\section{Abstract}

Lost, lost, lost (1976), by Jonas Mekas, retraces the route of a journey started with an involuntary distancing process from a region of origin. We discuss the heterogeneous registration strategies and the privileged modes of material composition in the process of weaving the narrative, to handle socio-historical and affective experiences evocated by the narrator-director. Due to the enigmatic way of editing the materials, analyzing the narrative poses a challenge, but we may still grasp the meaning of the proposed design of the journey. We show that the final recomposition, by the narrator, of himself addresses the emerging sense of belonging referring to the collective dimension.

\section{Keywords}

Territory, journey, belonging, Mekas. 


\section{Uma expressão cinematográfica da experiência do deslocamento}

A partir do advento do cinema moderno, que surge dos escombros da Segunda Guerra, surgem novas abordagens, de cunho mais ensaístico, nas fronteiras do cinema documentário. Nas abordagens cinematográficas mais instigantes se configura uma maior compreensão da dimensão antropológica do deslocamento espacial e das experiências existenciais de distanciamentos de territórios de origem. A travessia de espaços sociais e geográficos distantes põe em jogo experiências de alteridade e favorece a emergência de narrativas a respeito da vivência da travessia do percurso.

Tal é o caso de Jonas Mekas, poeta e cineasta originário da Lituânia. Envolvido em atos de resistência à ocupação alemã, perseguido pelos nazistas, deixou o seu país em 1944 e transitou, durante quatro anos, por diferentes campos para Displaced People (DP), neologismo forjado pelos aliados, no pós-Segunda Guerra Mundial, para designar civis que em função do conflito se encontravam, involuntariamente, fora das fronteiras nacionais dos seus países de origem.

Em 1949, Jonas conseguiu emigrar para os Estados Unidos da América (EUA), junto com Adolfas, um dos seus irmãos. Desde a saída de Semeniskai, a sua cidade natal, vinha mantendo um diário escrito. As suas fragmentárias anotações foram reunidas e posteriormente publicadas, décadas após, com o significativo título: Eu não tinha para onde $i r^{3}$.

Entre muitas outras ocorrências e reflexões, transcritas ao passar do tempo, o autor evoca, em um escrito datado de 29 de outubro 1949, o impacto causado pela entrada em Nova York do transatlântico do qual, ainda na véspera, era um dos anônimos passageiros:

Estávamos no convés do navio [...] 1352 pessoas deslocadas contemplavam a América. Ainda estou olhando para ela, na minha memória retiniana. Não se pode descrever este sentimento ou esta imagem a alguém que não viveu esta experiência. Toda a duração do conflito, todas as infelicidades do pós-guerra para as pessoas deslocadas, o abatimento e o desespero, 
e, de repente, um sonho que se ergue na sua frente. É preciso ver Nova Iorque desse jeito, de noite, desde o rio Hudson para apreender a sua incrível beleza [...]. Muito cedo de manhã um espesso nevoeiro reinava sob o porto. [...] A Estátua da Liberdade desvendou-se por um instante - para nos desejar boas vindas - e mergulhou novamente na bruma. Lentamente o navio dirigiu-se para o próprio coração de Nova Iorque [...] O oceano ainda estava presente nos nossos ouvidos e nas nossas carnes. Sentíamos simultaneamente tontos e extasiados ao tocar a terra firme. (MEKAS, 2004, p. 283-284, tradução minha)

Ao chegar a Nova York, Jonas compra uma pequena câmera Bolex 16 mm, graças à qual constitui uma espécie de diário fílmico, registrando, por intermitência, mas de modo persistente, momentos do dia a dia, cenas de encontros, performances e demais situações observadas e/ou vivenciadas. Desenvolve esta inovadora práxis, até então inédita no campo cinematográfico, sem ter previamente elaborado um projeto muito bem definido do tipo de aproveitamento possível do material recolhido.

A partir de planos filmados por mais de duas décadas, o cineasta monta, a partir de 1969, uma série de filmes, entre os quais se destaca Lost, lost, lost (1976), obra de cunho ensaístico, que dialoga com a tradição romântica das narrativas de formação, na qual a errância do protagonista da estória desempenha papel central.

\section{Ecoar o escoar interno do movimento da travessia}

Redigido muitos anos após a ocorrência das cenas registradas e enunciado por Jonas com sutis gradações de ritmo, tom e sotaque, o texto em inglês da narração tem uma dimensão essencialmente memorialística e autorreflexiva. A lembrança do passado ocorre na confluência de diversas memórias coletivas. A mais pregnante, inicialmente, é a do exílio.

As falas em voz over, apesar de seu caráter frequentemente elíptico e enigmático, desempenham papel central na condução da narrativa e na configuração de uma expressão audiovisual da subjetividade cindida do exilado, bem como do processo mnemônico vivenciado pelo narrador-diretor no seu esforço de rememoração da sua trajetória existencial no curso dos primeiros quatorze 
anos de sua vida nos EUA. A sua voz é a única que ouvimos em todo o filme. Todos os planos do filme foram registrados sem som.

O filme é dividido em seis partes, diferenciadas por simples cartelas que indicam o número do rolo ao qual corresponde. A narrativa de cada parte é pontuada por um grande número destes intertítulos, que trazem informações que contextualizam os registros visuais, e também desempenham função poética e emotiva, potencializando a força evocativa de instantes do passado.

Em função da fragmentação da montagem e do entrelaçamento recorrentemente enigmático das matérias de expressão (imagens, trechos musicais, falas em voz over, intertítulos na tela), o acompanhamento da recomposição, pelo filme, da evolução da trajetória do protagonista, no curso da narrativa, não é fácil de ser apreendida. Exige uma particular atenção, do movimento gradual do desenrolar das sequências, de um rolo ao outro, durante o visionamento do filme, para que possa ser progressivamente apreendido o desenho da travessia do herói que a trama compõe.

\section{Uma expressão problemática e lacunar dos anos iniciais do exílio}

Predomina, nos dois primeiros rolos, a busca de uma expressão, problemática e lacunar, da experiência dos anos iniciais do exílio, parcialmente compartilhada com os conterrâneos deslocados de guerra.

O filme abre com uma poética invocação da mitológica figura do errante navegante Ulisses, inscrevendo o relato fragmentado a seguir na grande tradição da literatura épica: "Oh cante Ulisses, cante as suas viagens. Conte onde esteve, o que viu, conte a história de homem que nunca quis deixar o seu lar" (LOST..., 1976) Cante como foi atirado mundo afora" (LOST..., 1976). Tal invocação irá se repetir, com formulações diversas, em alguns momentos estratégicos do desenrolar da narrativa.

No primeiro rolo é sublinhado o árduo trabalho de reminiscência do enunciador e a sua solidão: "Pelas ruas do Brooklin/Pelas ruas do Brooklin caminhei/Caminhei com o coração chorando de solidão" (LOST..., 1976). Simultaneamente, nos rolos iniciais, através de múltiplos registros das mais diversas situações, é trazida, 
com uma tonalidade elegíaca, a memória de momentos do cotidiano da comunidade lituana exilada em Nova York, na primeira metade dos anos de 1950. Seja em residências de amigos e conhecidos, ou em espaços públicos de convivência. Ou ainda nas ruas do Brooklin.

O estilo documental das tomadas nas ruas, em uma época onde estas ainda eram um lugar de maior convivência diária entre vizinhos, encontra correspondência com a tradição nova-iorquina da street photography e com o estilo de filmagem das ruas da cidade encontrado no curta-metragem In the street (1952), rodado na segunda metade dos anos 1940 no Harlem e dirigido por Helen Levitt ${ }^{4}$ - grande fotógrafa americana de origem russa, antiga colaboradora de duas das principais figuras da fotografia do século XX, Walker Evans e Henri Cartier-Bresson.

Mesmo nestas tomadas de composição fotográfica mais discreta, há um uso recorrente, por Jonas, de movimentos de câmera cuja motivação, nos rolos iniciais, parece ser de natureza mais descritiva do que lírica, contrariamente ao que irá acontecer mais adiante. De modo intermitente, surgem planos que fugazmente nos mostram fragmentos do diário escrito do diretor. O movimento da câmera sobre as páginas destaca algumas palavras que sutilmente dialogam com as suas falas em voz over e as imagens.

No final do primeiro rolo, é brevemente evocada a expectativa dos exilados lituanos, então compartilhada, na aurora da década de 1950, pelo enunciador "pensávamos que tudo isso era temporário" (LOST..., 1976) -, de um retorno, num futuro próximo, ao país, em função de um parâmetro que permanece oculto, ou seja, de uma mudança rápida do regime político responsável pela expatriação.

Para além das alusivas referências às dificuldades de sobrevivência, ao trabalho em fábrica ou em precárias ocupações, do protagonista, que irão persistir até o rolo três, destacam-se, a partir do segundo rolo, recorrentes sequências nas quais são poeticamente evocadas questões relacionadas à dimensão política do exílio lituano nos EUA em tempos da Guerra Fria. 
Surgem cenas mostrando reuniões políticas, em prol da independência da Lituânia, envolvendo militantes inominados e figuras de destaque, tais como Steponas Kairys, signatário da histórica declaração de independência do país, de 1918, ou de Povilas Žadeikis, antigo embaixador da Lituânia independente, em Washington. São mostrados desfiles e manifestações, de afluência relativamente escassa, em ruas de Nova York, nas quais pululam faixas e bandeirolas antissoviéticas, anticomunistas ou que denunciam, mais simplesmente, deportações em massa que estariam ocorrendo na Lituânia 5 .

Paralelamente, no curso das mesmas sequências, entremeando planos, ouvimos reiteradas falas em voz over enfatizando a função de testemunho do diretor-cinegrafista, afirmando que queria "ser a câmera historiadora do exílio e estava lá para registrar paixões conflituosas" entre comunistas e nacionalistas lituanos (LOST..., 1976). Persistentes alusões são feitas à fragilidade geopolítica deste pequeno país báltico, imprensado entre a União Soviética e a Alemanha, e nova invocação é feita, neste contexto, a Ulisses: "Oh, canta Ulisses, o desespero do exílio, o desespero dos pequenos países" (LOST..., 1976).

Narrador não confiável, Jonas aponta para o possível despertar de emoções frente à visão retrospectiva das ocorrências registradas, deixando obscuro, entretanto, neste momento preciso, o seu efetivo sentimento: "eu era o olhocâmera [...] o testemunho [...] registrava tudo. E eu não sei, estou eu cantando ou chorando?" (LOST..., 1976).

No primeiro rolo, junto com um plano que mostrava jovens pais jantando com os filhos em volta de uma mesa, a voz pontuava: "Tudo é muito normal. a única coisa que não saberemos jamais é o que pensa uma pessoa deslocada, à noite, em Nova Iorque" (LOST..., 1976).

Através destes apontamentos enigmáticos, o enunciador parece querer despertar a atenção do espectador sobre a dimensão inevitavelmente lacunar da representação possível de ser oferecida da experiência vivida. 
Cabe ressaltar que tal uso da voz over, aqui, e a problematização da representação que ela produz, guarda correspondência com o novo tipo de comentário, inquieto e interrogativo, que surge nos documentários mais lúcidos do pós-guerra, tais como Noite e neblina (1956), média metragem de Alain Resnais, muito admirado por Jonas - que considerava este filme como o melhor do diretor francês.

No final do segundo rolo, sobre novas imagens de encontro grupais da comunidade lituana, voltam referências a discussões relativas à independência da Lituânia e à determinação do enunciador de registrar "o que acontecia [...] para a história, para aqueles que não conhecem a dor do exílio" (LOST..., 1976).

O sutil subsequente encadeamento de planos, falas e motivos musicais sugere que a dor vivenciada por Jonas, neste estágio do seu desterro, esteve relacionada ao seu distanciamento da sua primeira comunidade de pertencimento nos EUA, a dos exilados lituanos - que persistia acreditando, sem dispor de elementos concretos para tanto, na possibilidade de um retorno ao território de origem.

Contrariamente, o enunciador aponta para um desejo difuso de libertar-se do que passou então a considerar como um aprisionamento nas recordações da vida anterior à vinda aos EUA: "Comecei a sentir, por volta desta altura, que eu andava em círculos no mesmo lugar em torno das minhas lembranças" (LOST..., 1976).

Em outras palavras, desejava extrair-se de uma postura nostálgica e melancólica frente à perda sofrida com o exílio, postura compartilhada pelo conjunto dos exilados lituanos, na visão homogeneizadora desta comunidade que o filme, em última instância, oferece.

Na sequência imediata do trecho de fala que acabo de citar, o enunciador ao mesmo tempo em que afasta a possibilidade de uma contribuição dos exilados ao estabelecimento de novos rumos para o seu país: "Comecei a achar que se houver algo a ser feito pela Lituânia, só poderia ser por aqueles que lá viviam". (LOST..., 1976). Aponta a utilidade, para o país, da sua reconstrução como individuo: "a única maneira, para mim, de ser útil à Lituânia consistia em me reconstruir, a recomeçar do zero, desde o início e então somente a me devolver à Lituânia por tudo que sou" (LOST..., 1976). 
Em função das rupturas vivenciadas com os seus grupos anteriores de pertencimento, da precariedade da sua situação e da ausência do estabelecimento de novos laços no território onde aportou, nenhum horizonte promissor de espera parecia, naquele momento, se abrir para Jonas.

Ao que tudo indica, é por isso, que após o desaparecimento das últimas imagens de um encontro de lituanos numa tarde de domingo, o segundo rolo se conclui com o surgimento repentino, porém duradouro, de uma tela preta. A tela permanece escura tempo suficiente para que a voz over do desterrado e solitário narrador enuncie: "Esse foi um dos nossos últimos momentos juntos. Tive a sensação de estar me desfazendo em mil pedaços. No dia seguinte deixei o Brooklyn e me mudei para Manhattan" (LOST..., 1976).

A junção das três frases, como vemos, associa o término da convivência com a comunidade lituana em exílio, a fragmentação do eu do enunciador, e o seu voluntário afastamento do bairro dentro do qual a maioria da diáspora lituana tinha estabelecido residência.

Como apontou Sayad (2000), a relação com o grupo encontra-se no nó das contradições que habitam a consciência de todo emigrante e imigrante, na medida em que todo individuo é membro de um grupo original, e em seguida, membro de outros grupos segundos, igualmente importantes para ele. Tal relação é sempre ambígua, marcada por uma consciência culpada em relação ao grupo que a pessoa deixou de fato. Neste quadro, o eu dividido em mil pedaços almeja assegurar-se, entretanto, de que o grupo não foi deixado afetivamente nem pelo coração nem pelo espírito, pois tal abdicação, em última instância, constituiria uma abdicação de si $^{6}$.

\section{Emergência de novos laços no território de arribação}

No curso dos dois rolos subsequentes, o espectador atento pode observar a progressiva emergência de novos laços no território de arribação. No início do 
terceiro, é feita breve referência, numa fala em voz over, à deambulação dos irmãos Mekas fora do perímetro mais restrito por onde circulava, em Nova York, a comunidade lituana em exílio: "tudo era novo, a cidade, as pessoas. Caminhamos pela cidade, nos imergimos nela" (LOST..., 1976).

Tal imersão, entretanto, não suscita no protagonista, nesta altura do relato de sua travessia existencial, nenhum sentimento de pertencimento. Contrariamente, no final deste rolo, enquanto se sucedem, na tela, imagens de uma estrada, registradas de um carro em movimento, é enunciada uma interrogação central que enfatiza a permanência de um estranhamento com o país para onde emigrou: "Eu olhava a paisagem. Eu sabia que eu estava na América. O que faço aqui, perguntei-me? Não havia resposta" (LOST..., 1976). Neste rolo, predomina, na trilha sonora, a música sinfônica do Parsifal de Wagner. As falas em voz over são mais rarefeitas do que nas outras partes do filme, mas comparecem em momentos estratégicos.

Duas sequências elipticamente evocam experiências iniciais do cineasta com longas metragens de ficção. Uma telegráfica e extremamente alusiva sequência refere-se de modo enigmático - e um tanto incompreensível para o espectador não informado -, ao alastramento, em uma rua de Nova York, da revista Film Culture, fundada por Jonas e Adolfas, em 1955 - e que progressivamente se tornou a principal revista dedicada ao cinema independente nos EUA.

Outras sequências documentam cenas de trabalho da cena artística nova-iorquina emergente do final dos anos de 1950 e início dos anos de 1960, tais como um encontro de poetas, integrantes da beat generation, na sede do Living Theater, célebre companhia de teatro dirigida por Julian Beck e Judith Malina.

É notável, ainda neste rolo, a aparição dos primeiros indícios de uma evolução no estilo de registro do cineasta, com o surgimento de planos nos quais o cinegrafista solta à câmera, em líricos movimentos gestuais. Em uma destas sequências, a mais sincopada, que dialoga com a percussão do grande baterista de jazz Joe Jones, que quase não aparece na cena, a voz over do enunciador volta a tematizar a função de registro da câmera, enfatizando a incorporação, por ele, da prática da documentação da vivência de instantes fugidios de sua travessia: 
"Os fragmentos que estou registrando com a minha câmera, estas imagens, estes lampejos que eu registrei nos lugares por onde passei. É agora da minha natureza registrar tudo o que eu atravesso. Ruas, rostos, cidades" (LOST..., 1976). A importância subjetiva destes registros, para o desterrado Jonas, entretanto, só será apontada bem depois, quase no final do próximo rolo.

Afora algumas poucas sequências com transeuntes comuns em Nova York e aquelas nas quais vemos Jonas com amigos, quase todas as cenas incluídas no quarto rolo envolvem manifestações de rua em prol da paz e contra a realização de testes nucleares, ocorridas em Nova York, durante a Guerra Fria. A maioria das situações mostradas estão relacionadas à campanha World Wide General Strike for Peace, de 1962, na qual se destaca a participação do movimento de mulheres na Women Strike for Peace.

No início deste novo segmento, o enunciador, ao enfatizar, novamente, o papel registrador da câmera, destaca a sua "estrangeiridade": "Eu era apenas um transeunte, vindo de alhures, de completamente alhures, observando tudo com a minha câmera e eu registrei, registrei tudo isso, não sei porquê" (LOST..., 1976).

Pouco depois, sobre imagens de uma manifestação no Greenwich Village, entretanto, sublinha pela primeira vez um sentimento de pertencimento, não ao país, mas à cidade onde aportou: "Eu estava com vocês. Eu precisava estar. Vocês eram o sangue da minha cidade, o bater do seu coração. Quis sentir seu pulso, sentir sua excitação. Sim, era minha cidade" (LOST..., 1976).

Mais adiante, em sequências que constituem uma crônica do rude inverno de 1962 em Nova York, destaca-se a participação em manifestações de rua de "mulheres militantes, desconhecidas, debaixo da chuva, da neve e do frio" (LOST..., 1976).

No final deste quarto rolo, junto a novos planos de manifestações pela paz, a voz usa o presente do indicativo, e não o pretérito, contrariamente ao que acontece na maioria das falas do filme, e diz: "É da minha natureza, agora de registrar, de tentar guardar tudo que eu atravesso, de preservar ao menos fragmentos Perdi demais. Então agora tenho fragmentos do que eu atravessei" (LOST..., 1976). 
Assim, se nos dois primeiros rolos, o enunciador ressaltava a importância do registro para uma historiografia do exílio, agora enfatiza a importância da documentação da vivência de instantes fugidios da travessia, para ele próprio, enquanto sujeito que, no curso do caminho, atirado mundo afora, teve a sensação de se desfazer em mil pedaços e perdeu demais. Tal afirmação aponta para um deslocamento da posição subjetiva do enunciador, dentro do movimento da narrativa. Não mais apenas lamenta perdas, mas se dispõe a processar vestígios de suas vivências, com vistas a um potencial futura elíptica recomposição do seu percurso.

\section{Celebração de (re)encontros}

As cenas de verão do início do quinto rolo, nas quais a luz do sol da região do Vermont parece transbordar pelas janelas, contrastam com as cenas invernais e as paisagens cobertas de neve da parte anterior. É notável também, nos dois últimos rolos, a transformação do modo de aparição do Jonas. Antes, pouco e fugazmente aparecia, e o seu semblante era quase sempre sério e austero. Agora, no rolo cinco, o cineasta surge alegre e brincalhão. Retrata-se como um tolo, que, só ou com seus amigos, faz palhaçadas. Nós o vemos assim, solitário, na parte baixa de uma colina inteiramente coberta de neve, dando pulinhos entusiasmados ou dançando e tocando, alegremente.

Não por acaso, tal movimento de dessacralização da figura do artista acontece em um momento do filme em que é poeticamente evocada uma etapa da sua trajetória na qual ocorreram mudanças radicais no seu estilo de filmar. A partir principalmente do quinto rolo, a função devoluta à câmera, para além da documentação da ação de terceiros, é de celebrar o encontro do cinegrafistadiretor com a natureza, com pessoas e com espaços habitados onde circula.

Através da movimentação do seu corpo e do desenrolar dos gestos das suas mãos, que livremente deslocam a câmera, em intensos movimentos líricos, há, em primeira instância, uma celebração de um reencontro com a natureza, que se concentra neste penúltimo rolo do filme. 
Particularmente durante uma primeira série de 56 brevíssimas sequências, de poucos segundos de duração, aqui, mais do que em qualquer outro rolo, cada sequência constitui um todo, uma forma breve, um poema, podendo, entretanto, cada um destes segmentos ser apreendido e situado dentro de um encadeamento narrativo mais abrangente.

Em boa parte das cenas de cunho epifânico que nos são dadas a ver, a voz over repete três vezes a mesma palavra, a semelhança do procedimento verbal usado para dar título ao filme: "Lost, lost, lost" (LOST..., 1976).

Estes são termos que remetem direta ou indiretamente ao que o espectador vê na imagem, dizem respeito à natureza (o gelo, a neve, o vento, o rio, as nuvens, as colinas), às suas estações (verão, outono, inverno), a instantes quaisquer do dia (a noite), a etapas da vida humana (a infância) ou ao afeto (a amizade).

O uso repetido de tercetos erráticos acentua o ritmo sincopado dos planos e parece constituir, neste penúltimo rolo do filme, como bem observou Rollet (1993), um gaguejar da memória, que tenta se lembrar. Um exercício mnemônico de atualização de lembranças, a busca de um encadeamento, no presente, do desenrolar de vestígios do passado.

No final da série dos haikus, surgem duas alegres e ensolaradas sequências reagrupadas por meio da inserção da cartela intitulada "Na cooperativa de cineastas", na qual, como de hábito, nenhuma informação factual é oferecida ao espectador a respeito desta entidade, que Jonas ajudou a organizar, em 1962, e constituiu uma primeira cooperativa de filmes independentes, dirigida pelos próprios cineastas. Entremeando rodopiantes planos em torno de rostos de pessoas presentes, vemos Jonas circulando no local e se movimentando junto a um rolo de filme que gira sobre o seu eixo.

\section{Um sentimento de desterro em estado latente}

Depois de uma nova série de haikus, que celebra de modo lúdico a amizade, o penúltimo rolo se conclui, enigmaticamente, por uma sequência que, de modo metafórico, alude à errância do deslocado. O segmento se inicia com uma série 
de cenas em que vemos, a distância, um grupo de mulheres na cercania de um prédio que a voz over alega ser de um asilo aonde teriam vindo visitar um amigo.

Em seguida, enquanto a câmera passa e circula por árvores e galhos em um bosque, a fala em voz over aponta que o narrador não sabe onde estariam as melhores cabeças de sua geração.

Logo depois, a câmera inicia uma série de giros de $360^{\circ}$, em torno da figura de um homem, enquanto as últimas frases do quinto rolo são ditas:

"Avanço em qualquer direção. Não sei para onde vou e não confio em nenhuma mente desde que deixei meu lar. As melhores cabeças de minha civilização me trouxeram para esta estrada, esta estrada que não tem fim. Esta estrada, esta jornada que não tem fim" (LOST..., 1976).

Nesse estágio do desenrolar do filme, que precede um bem mais auspicioso final, a inclusão de tal fala parece apontar para a inevitabilidade da persistência latente do sentimento de desterro na economia psíquica da pessoa expatriada, para além das eventuais e positivas alterações porventura advindas nas suas condições de vida após a sua chegada.

Como acentuou no final de um dos seus ensaios, Said (2003, p. 60):

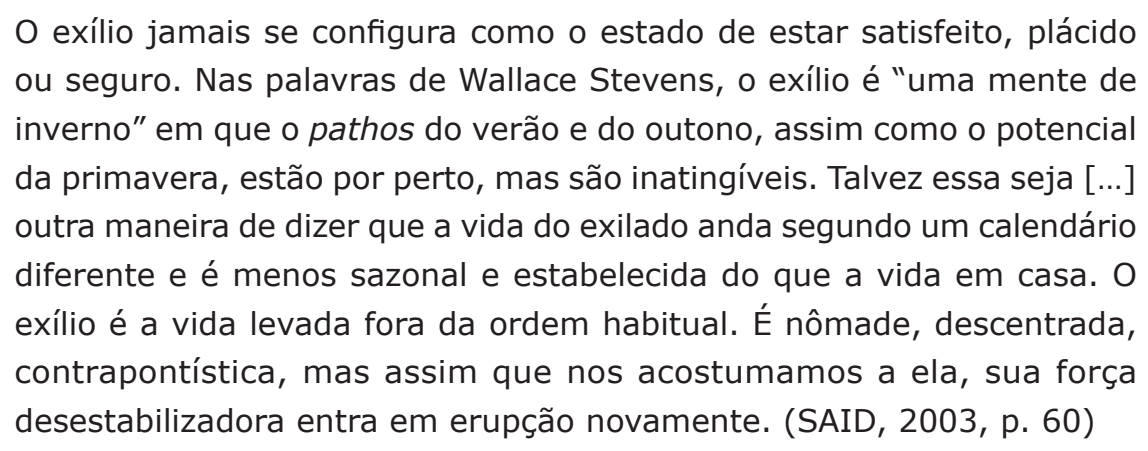

É como se, antes do auspicioso final do filme, o enunciador almejasse metaforicamente inserir uma alerta: o expatriado involuntário pode vir parcialmente a se acostumar a levar a sua vida fora da ordem habitual, mas sempre haverá de persistir, em estado de latência, na sua economia psíquica, um sentimento de desterro, uma irreversível sensação de deslocamento no presente da vivência dos lugares. 


\section{Pertencimento a uma nova ordem}

Os mais virtuosos movimentos de câmera e a mais lírica ode audiovisual do filme encontram-se no início do rolo final, quando é elipticamente evocada a ida de Jonas, junto com amigos ${ }^{7}$, para o celebrado Seminário Flaherty, que desde 1955 promovia encontros, debates e projeções de filmes documentários, frequentemente inéditos.

Aqui, além de uma exaltação à natureza, há, em última instância, uma exaltação ao exercício da liberdade de criação e a inovadora ampliação dos recursos expressivos do cinema levada a cabo pela vanguarda cinematográfica norte-americana, da qual Jonas era então um dos integrantes mais expressivos.

Para explicitar o modus operandi desta nova práxis artística, o diretor solicitou ao seu parceiro, Ken Jacobs, que com uma segunda câmera, o filmasse, lépido e fagueiro, volteando com a sua própria câmera no meio de um gramado alto, enquanto principal protagonista de uma cena de alto valor simbólico. E, na montagem, alternou planos das duas câmeras.

Uma cartela, no início do sexto rolo informa que os amigos levavam cópias de dois filmes sobre os quais nenhuma informação é dada, a não ser o nome do título de cada um: Flaming creatures e Blonde cobra ${ }^{8}$.

Uma outra cartela informa que "Expulsos do seminário Flaherty, dormimos na noite glacial do Vermont" (LOST..., 1976). Nenhuma relação de causa a efeito é apontada entre as duas obras trazidas e a expulsão do grupo de amigos do local.

Após a cartela, vemos uma série de imagens de um amanhecer, com luz estourada, e pessoas acordando em veículos situados juntos a uma casa, entre as quais se destaca Jonas. Na trilha, ouvimos a voz do cineasta dizer:

Enquanto os convidados, documentaristas respeitáveis, importantes cineastas, dormiam em suas camas quentes, nós víamos o amanhecer com o frio da noite ainda em nossos ossos, em nossa carne [...] Nós nos sentimos mais perto da terra e da manhã do que as pessoas nas casas. Nós 
nos sentimos parte da manhã, da terra. Estava muito, muito quieto. Como numa igreja. E nós éramos os monges da Ordem do cinema. (LOST..., 1976)

A partir daqui, como bem observou Mourão (2016), a sequência adquire um caráter místico-religioso, introduzindo um ritual de sagração e de ordenação de Jonas e seus companheiros:

\begin{abstract}
À menção à igreja e a ordem, seguem-se sons de sino; a câmera ganha velocidade e percorre, de perto, em movimento aparentemente desordenado e sem preocupação com o foco, um gramado. Imagens abstratas, intercaladas com imagens de Ken Jacobs filmando e breves planos de outras pessoas presentes. Ainda sob o som dos sinos, vemos Mekas com um cobertor sobre os ombros, que não deixa de lembrar um manto monástico, abrir os braços, levar a sua câmera ao olho, espelhando e refletindo o olhar de Jacobs que o filma, e depois curvar-se, afastar a câmera do seu olho, dirigi-la ao chão, começar a andar em zigue-zague quase dançando como se o cobertor/manto fosse um parangolé e a câmera o volante de um carro imaginário em uma brincadeira infantil. Os sinos silenciam-se, e, então ouve-se trechos de uma missa. (MOURÃO, 2016, p. 182)
\end{abstract}

O ritual evocado simbolicamente consagra o papel devotado à vanguarda cinematográfica americana surgida no decorrer dos anos de 1950 e destaca o protagonismo do Jonas neste processo.

De modo mais encoberto, mas sensível, entre outros, pelo uso reiterado do pronome "nós", a sequência aponta para a consolidação, no âmbito mais subjetivo da intimidade do narrador, de um sentimento de pertencimento a uma comunidade, algo essencial para aquele que tinha sido atirado mundo afora, que durante muito tempo pelas ruas caminhou com o coração chorando de solidão, e no sofrido processo do exílio teve a sensação de se desfazer em mil pedaços.

Tal dimensão mais subjetiva encontra-se, diferentemente, enfatizada na última sequência, colorida, do filme, composto majoritariamente de imagens em preto e branco, na qual é evocada uma ida à praia de Stony Brook, com Ken Jacobs e duas amigas, no início dos anos de 1960. Paradoxalmente, aqui, ao concluir o relato de sua travessia, o narrador usa, de modo brusco e alternado, 
a terceira e a primeira pessoa do singular, referindo-se a si mesmo como um outro, no próprio instante em que exalta o ressurgimento de lembranças.

Há uma correspondência sutil deste desdobramento pronominal com a estratégia de registro e de exposição adotada na sequência final. Não por acaso, o espectador assiste a cenas desta visita a praia registradas, por um lado pelo Ken, e por outro pelo Jonas.

Os nomes dos dois cinegrafistas encontram-se indicados por cartelas, como na sequência do Seminário Flaherty. Naquela sequência anterior, entretanto, havia mescla dos planos das duas câmeras.

Nesta, a filmagem do Ken e a do Jonas nos são apresentadas em dois segmentos sucessivos, em que predominam planos curtos e sincopados das duas amigas se divertindo e tomando banho de mar, vestidas, com água até a cintura. Estes planos se misturam com outros, registrados nas redondezas da praia. Como a de um cavalo branco, símbolo da Lituânia, com o qual os protagonistas das cenas se relacionam, em um campo de pastagem.

No primeiro segmento, intitulado "Filmagem do Ken", na qual Jonas aparece, diversas vezes, filmando, a voz over aponta que as amigas tinham insistido para ir nadar de roupa e usa a primeira pessoa do plural para poeticamente evocar o momento epifânico ao qual alude. "Era um destes claros e ensolarados dias de outono" (LOST..., 1976), diz o enunciador, "andamos ao longo da baía, na praia" (LOST..., 1976). O mar carregava ao longe todas as nossas preocupações com as suas águas. Tudo que o mar não podia levar o era pelas cores do outono" (LOST..., 1976).

No segundo segmento, intitulado "Filmagem de Jonas", em que os planos se sucedem num ritmo em staccato ainda mais acentuado, o narrador se refere a si mesmo como outro. Remete ao seu deslocamento de um lugar e à superposição de tempos: "Às vezes ele não sabia onde estava, o passado e o presente entremeados, sobrepostos. E como nenhum lugar era realmente o dele, como nenhum lugar era realmente a sua casa, ele tinha esse hábito de se apegar imediatamente a qualquer lugar" (LOST..., 1976). 
Como sabemos a superposição de tempos é um traço característico da dimensão essencialmente dinâmica da memória, palavra que, "no seu sentido antigo, designa uma presença à pluralidade dos tempos e não se limita ao passado" (CERTEAU, 1990, p. 335).

A ida à praia de Stony Brook, para o narrador, parece ter constituído o momento oportuno para um redentor desengate de reminiscências, no curso do qual ocorre o repentino salto da terceira para a primeira pessoa do singular: "Ele se lembrou de outro dia, dez anos atrás. Ele se sentou nessa praia, dez anos atrás, com outros amigos. As lembranças, as lembranças, as lembranças. Mais uma vez, eu tenho lembranças. Eu tenho lembrança desse lugar. Eu já estive aqui. Eu realmente já estive aqui. Eu já vi esta água antes. Sim, eu já andei por essa praia, em cima destas pedrinhas" (LOST..., 1976).

Neste momento final do sexto rolo, quando a voz do Jonas pronuncia as últimas frases, talvez tenha se esvanecido, na memória do espectador desta obra de aproximadamente três horas de duração, a lembrança de uma cena do primeiro rolo, em que era evocada uma ida para a Stony Brook com três amigas, que alegremente dançavam, vestidas, na beira da praia. Cena associada então a uma sombria e metafórica meditação sobre a morte espiritual dos imigrantes lituanos melancolicamente presos ao passado e à ilusão da possibilidade de um retorno próximo à terra de origem.

O dilaceramento do narrador, enfatizado no final do segundo rolo, estava relacionado ao seu distanciamento desta comunidade de pertencimento, vivenciado então com um segundo e ainda mais solitário exílio.

A simples vivência pelo protagonista de um novo estar junto, naquela mesma praia, numa tarde de um dia qualquer ("Era um destes claros e ensolarados dias de outono" (LOST..., 1976) com um novo grupo de amigos, aos quais encontra-se ligado por laços de pertencimento que transcendem a dimensão puramente afetiva e remetem à dimensão da cultura e do compartilhamento de um ethos comum, no território de arribação, reaviva a lembrança daquele momento de incerteza posterior a sua chegada, compartilhado com aquela outra comunidade de pertencimento. $\mathrm{O}$ 
surgimento de tal reminiscência, ao que tudo indica, torna-se possível pela efetuação do trabalho do luto, que a própria conclusão do filme significou.

O que pode ser considerado, ao cabo do relato, como uma recomposição, pelo narrador, do seu próprio eu, encontra-se intrinsecamente relacionado, como se vê, à consolidação da emergência de um novo sentimento, íntimo, de pertencimento que remete, entretanto, à ordem do coletivo.

Patriota, Jonas se envolveu, na casa dos 20 anos, em atos de resistência contra a ocupação nazista, motivo pelo qual foi obrigado, como mencionamos, a fugir do seu país em 1944, e o levou, após cinco anos de errância em campos de trabalho forçado ou para pessoas deslocadas, a emigrar para os Estados Unidos.

Ao desenrolar do filme, depois da intrincada alusão do narrador, no final do rolo dois, a sua eventual contribuição futura, como individuo exilado, aos destinos do seu país, não há mais referência verbal à pátria de origem, nem nomeação do novo território nacional para onde emigrou.

No decorrer do quarto rolo, diante das seguidas manifestações mostradas pela paz, como apontamos, é verbalmente expresso o sentimento de pertencimento à pólis nova-iorquina que os manifestantes, moradores da cidade, parecem, para o enunciador, representar: "Eu estava com vocês. Era preciso. Vocês eram o sangue da minha cidade, o bater do seu coração. Quis sentir seu pulso, sentir sua excitação. Sim, era minha cidade" (LOST..., 1976).

Em diversos momentos, nos rolos subsequentes, diversas composições audiovisuais exaltam o sentimento cósmico, panteísta, de pertencimento à natureza.

Se tal ausência de referência de um sentimento de pertencimento a uma comunidade nacional pode ser constatada para além das motivações relacionadas à condição de pessoa deslocada, talvez seja também porque, para Jonas, filho de camponês, concreto era o chão da sua aldeia natal, como escreveu em um trecho do seu diário:

Eu penso nunca ter sido um bom patriota, do modo que os nossos amigos lituanos o são. Nem o Adolfas. Eles amam o seu país, a sua pátria. Mas nós, nos sentimos ligados apenas a Semeniskai, nossa pequena aldeia e 
aos lugares próximos, as pessoas que lá vivem e ao campo. Isto não tem nada a ver com nacionalismo. Somos regionalistas... O tempo. As estações que ritmam o ano. As ínfimas nuances da natureza. A cor dos prados em cor. A vegetação lá é muito peculiar. Não me diga que isto é apenas romantismo, sentimentalismo etc. Tudo isso é extremamente concreto. Nossos movimentos, nosso modo de caminhar. Nosso sotaque. Tudo é determinado, impregnado pelo clima, pela paisagem, pelo sol sob o qual crescemos. Não se trata apenas de lembranças. (MEKAS, 2004, p. 376, tradução minha)

\section{Lampejos de uma topografia mística}

Tal sentimento primevo de pertencimento à terra natal é poeticamente explorado no filme anterior do realizador, intitulado Reminiscências de uma jornada à Lituânia (1972). Por razões que não se encontram explicitadas no filme, o realizador, após 25 anos de ausência teve excepcionalmente a oportunidade de uma breve volta ao seu país, à cortina de ferro imposta pelo regime soviético impedindo durante várias décadas qualquer contato com o Oeste.

Em um breve segmento inicial, Jonas introduz uma série de imagens em preto e branco, acompanhada de comentários em voz over, dos primeiros tempos de sua chegada, nos anos de 1950, em Nova York, que permitem ao espectador resumidamente entender porque o narrador permaneceu tantos anos sem voltar ao seu país.

Na maior parte do filme, entretanto, vemos registros datados de 1971, coloridos e fugidios, dos reencontros ocorridos na jornada de volta, com espaços, situações e pessoas da sua família, entre os quais se destaca a sua mãe. Tais planos encontramse associados a falas, de cunho memorialístico, enunciadas por Jonas, a respeito dos sentimentos envolvidos no seu retorno à casa e à terra natal, Semeniskai.

O decorrer sincopado das imagens provoca uma instabilidade na representação das situações documentadas e a inter-relação construída pela montagem com as falas acaba constituindo uma instigante figuração audiovisual do intricado processo de reminiscência vivenciado pelo diretor nesta tardia volta ao país natal. Há uma fulgurante exploração dos espaços circunvizinhos à casa natal e das figuras familiares que por lá circulam. 
Semeniskai, com o tempo, tornou-se lugar de intenso investimento da cultura nostálgica. Como Sayad nos lembra, a nostalgia do lugar tem um grande poder de transfiguração de tudo que toca. Produz efeitos de encantamento, e mais ainda, efeitos de sacralização e santificação. "O país, o solo natal, a casa dos antepassados, e mais simplesmente, a casa natal, cada um desses lugares privilegiados da nostalgia (e pela nostalgia)", que são lugares da natureza e da história, tornam-se lugares sacralizados, lugares benditos, terras santas, para os quais se vai em peregrinação (SAYAD, 2000, p. 13). São lampejos desta topografia mística que na parte central do Reminiscências de uma jornada à Lituânia, Jonas nos dá a ver.

Lost, lost, lost foi lançado em 1976, depois da estreia de Walden em 1969, e de Reminiscências de uma viagem a Lituânia, em 1972. Neste último filme foram incluídos registros efetuados pelo cineasta nos anos de 1950, que irão reaparecer em Lost, lost, lost, concluído e lançado em 1976. Nenhuma gravação, entretanto, realizada por Jonas, por ocasião da volta ao território de origem, em 1972, aparece no último, composto apenas por material captado entre 1949 e 1963.

\section{O sentido do desenho do movimento da narrativa}

Tal decisão de montagem, evidentemente, encontra-se vinculada ao modo de construção narrativa da obra de 1976. Tratava-se aqui, para Jonas, de desenhar o sinuoso movimento de recomposição da memória do trajeto do narrador, que partiria da involuntária e solitária condição de expatriado recém chegado em uma nova terra de arribação e haveria de evocar a amplidão do seu desassossego e a persistência latente do sentimento de desterro na sua economia psíquica, dilacerada, para além de eventuais e positivas alterações advindas nas suas condições de vida após a sua chegada. Ao cabo, entretanto, como procuramos demonstrar, o movimento da narrativa deveria apontar para uma recomposição pelo narrador do seu próprio eu.

Recomposição anterior a sua viagem de volta a Lituânia, e intrinsecamente relacionada, como vimos, à consolidação da emergência de um novo sentimento, íntimo, de pertencimento a um novo grupo, o dos cineastas de vanguarda norteamericanos do início dos anos 60. 


\section{Referências}

CERTEAU, M. A invenção do cotidiano 1: artes do fazer. Rio de Janeiro: Vozes, 1990.

IN THE STREET. Direção: Helen Levitt, Janice Loeb e James Agee. Nova York: [s. n.], 1952. 1 vídeo (17 min), p\&b.

LOST, lost, lost. Direção: Jonas Mekas. Nova York: [s. n.], 1976. 1 vídeo (176 min), p\&b.

MEKAS, J. Je n'avais nulle part où aller. Paris: POL, 2004.

MOURÃO, P. A invenção de uma tradição: caminhos da autobiografia no cinema experimental. 2016. Tese (Doutorado em Meios e Processos Audiovisuais) Universidade de São Paulo, São Paulo, 2016.

NOITE e Neblina. Direção: Alain Resnais. Paris: [s. n.], 1956. 1 vídeo (32 min), p\&b, color.

REMINISCÊNCIAS de uma viagem a Lituânia. Direção: Jonas Mekas. Nova York: [s. n.], 1972. 1 vídeo (88 min).

ROLLeT, P. Les exils de Jonas Mekas. Cahiers du Cinéma, Paris, v. 20, n. 463, p. 68-72, 1993.

SAID, E. Reflexões sobre o exílio e outros ensaios. São Paulo: Companhia das Letras, 2003.

SAYAD, A. O retorno, elemento constitutivo da condição do imigrante. Travessia, São Paulo, ano XIII, n. especial, p. 7-32, 2000. 